Hammer, D., and Herrero, S. 1987. Grizzly bear food and habitat in the Front Ranges of Banff National Park, Alberta.

Hammer, D., and Herrero, S. 1990. Courtship and use of mating areas by grizzly bears in the Front Ranges of Banff National Park, Alberta. Canadian Joumal of Zoology 68: 2695-97.

Hansson, R. 1991. Summary of polar bear migration studies in southern Svalbard 1987. In: Amstrup, S., and Wiig, $\varnothing$. (editors). Proceedings of $I X$ meeting of IUCN Polar Bear Specialist Group, Sochi 1988: 3435.

Hansson, R., Jensen, P. M., and Thomassen, J. 1987. Migration of polar bears (Ursus maritimus) in Homsund and south-east Svalbard 1987. In: Prestrud, P. and Øritsland, N. A. Miljeundersekelser i tilknytning til petroleumsvirksomhet pá Svalbard
1987. Norsk Polarinstitut Rapport 41:25-78

Larsen, T. 1986. Population biology of the polar bear (Ursus maritimus) in the Svalbard area. Norsk Polarinstitut Skrifter 184.

Malyov, A. V. 1990. Reproduction and sexual behaviour of polar bears (Thalarctos maritimus Phipps) in the Kazan' Zoobotanical Garden. In: Amstrup, S., and Wiig, $\varnothing$. (editors). Proceedings of the IX meeting of IUCn Polar Bear Specialist Group, Sochi 1988.

Murie, A. 1981. The grizzlies of Mount McKinley. Washington DC, US Department of the Interior, National Park Service, Science Monograph Series no. 14.

Ramsay, M. A. and Stirling, I. 1986. On the mating system of polar bears. Canadian Journal of Zoology 64: 2142-51.

\section{The interaction of science and politics in the field of international relations: the case of Antarctica}

\section{Lucius Caflisch}

Federal Department of Foreign Affairs, 3003 Berne, Switzerland

\section{Received July 1991}

\section{Introduction}

This paper is concerned with the interplay between science and politics when dealing with the formation and implementation of international rules of conduct for the Antarctic. The two questions to be addressed are: (1) how do scientific concerns influence Antarctic politics and (2) how do politics affect scientific activities in Antarctica and the surrounding seas?

In the context of this paper, 'science' includes both pure and applied scholarly investigation about the Antarctic, comprises activities in the realm of natural and relevant social sciences (political science, including security studies, international law and economics, and the history of discoveries), and encompasses the training of young scientists, who should be afforded the opportunity to spend time and conduct research on Antarctica whenever appropriate. 'Politics' may be described as the art of shaping rules for human conduct in the Antarctic. The main difficulty in this endeavour has been that seven states (Argentina, Australia, Chile, France, New Zealand, Norway, and the United Kingdom) advance partly conflicting claims to territorial sovereignty over large portions of the continent and the adjacent seas (Auburn 1982), while most other countries resist those claims. A common denominator has finally emerged: a 'bifocal' regime that freezes national territorial claims without prejudicing them, while placing Antarctica under the collective management of the interested states.

At least partial answers to the paper's initial queries may present themselves if the behaviour of the main political actors on the Antarctic scene is examined, that is, the conduct of sovereign states and of international inter- governmental or non-governmental organizations.

\section{States as actors in the Antarctic framework}

The regime instituted by the Antarctic Treaty of 1 December 1959 (United Nations Treaty Series 1961, 402: 71), which has been added to ever since, was shaped by three main factors: (1) the strategic race that, in the context of the cold war, threatened conflicts of interest between the Soviet Union and the United States on the seventh continent; (2) the disputes between states with overlapping territorial claims (Argentina, Chile, the United Kingdom), which carried a threat to international peace and security; and (3) the general wish to pursue and intensify the scientific cooperation successfully inaugurated by the International Council of Scientific Unions (ICSU) during the International Geophysical Year (IGY) of 1957-58. Potentially as disruptive as the conflicts between the Soviet Union and the United States were the disputes brought before the International Court of Justice by the United Kingdom, against the wishes of Argentina and Chile; the Court declared itself to be without jurisdiction.

These three factors - two of which may be deemed political, while the third relates to science - are fully reflected in the Treaty of 1959 , which outlawed military activities in the area, including nuclear explosions, thereby establishing the world's first zone of peace (Articles I and V); submitted control of the Antarctic to an international regime neutralising existing territorial controversies (Article IV); and developed a set of rules postulating freedom of scientific research and international scientific cooperation (Articles II and III).

It may be said that both politicians and scientists stood solidly behind the 1959 instrument, although for differing reasons. The same is true regarding the Treaty's institutional provisions (Article IX), which divide the Antarctic states into two categories: Consultative Parties (the 12 signatories of the Treaty and those parties that have shown their effective interest in Antarctica by undertaking or sponsoring in or around the continent activities such as the establishment of stations or the organisation of expedjtions) and simple Contracting Parties. To put it bluntly, the former make the decisions, while the latter, having mere 
observer status (Recommendation 15 of the Thirteenth Antarctic Treaty Consultative Meeting in 1985), are excluded from the decision-making process. This discriminatory dichotomy, which has come under increasing attack since the early 1980s (Treves 1987: 281-89), was perhaps justified in the 1960s and 1970s, when Antarctic activities focused on scientific matters: the basic legal rule of effectiveness suggested that the states undertaking or sponsoring such activities should equally be called upon to regulate and supervise them.

The distinction between Consultative Parties and simple Contracting States is perhaps less justified today, as other matters are gaining importance, for example, fishing and hunting, mining activities, tourism, and the preservation of the environment. The protection of the environment, for instance, undoubtedly concerns the international community as a whole; why, then, should some states be more equal than others when it comes to establishing an international environmental regime for the Antarctic region?

Since its entry into force on 23 June 1961, the Antarctic Treaty, originally signed by 12 states, has been acceded to by 27 states. Thus, the present constituency amounts to 39 states, one-third of which have remained simple Contracting Parties while two-thirds enjoy consultative status. In the context of the interrelation between politics and science, it might be interesting to examine why countries have resolved to join the Treaty. A good example of differing motivations is provided by Austria and Switzerland, both of which at present are Contracting Parties.

Austria decided to accede to the Antarctic Treaty in 1987 without having previously acquired associate membership in the Scientific Committee on Antarctic Research (SCAR) of ICSU. This element, among others, suggests that the Austrian decision was essentially a political one, possibly prompted by the desire to promote the political goals of the Treaty, also perhaps by the wish for a higher profile on the international scene. The decision met with no opposition in the Austrian Parliament or public. It is now, a posteriori, that the Austrian authorities are beginning to take stock of possible research activities by their country.

In Switzerland a Committee for Polar Research was founded in 1984 by interested scholars under the auspices of the Swiss Academies of Natural, Technical and Human Sciences. In 1987 the Committee obtained associate membership in SCAR. At about the same time, Swiss scientists began to find it increasingly difficult to pursue their work by seeking admission to research teams of some Antarctic states; those states and their scientists may have thought, quite properly, that if Switzerland were unwilling to become part of the Antarctic system, there was no reason why its scientists should continue to benefit from the costly infrastructures established and financed by others. Accordingly, the Committee for Polar Research requested the Swiss Foreign Ministry to consider the accession of Switzerland to the 1959 Treaty. The Ministry responded favourably but, unlike their Austrian colleagues, had some internal opposition toovercome before Switzerland could ask for admission to the Antarctic system. Switzerland acceded to the Antarctic Treaty on 15 November 1990 . after all the Consultative Parties had given their consent.

The preceding description illustrates two radically different approaches, one political, and the other based on scientific considerations. It is not aimed at passing judgement. There is nothing wrong in wishing to join the Antarctic community in order, for example, to contribute to the status of Antarctica as a nuclear-free and nonmilitarised zone, rather than for reasons primarily connected with the advancement of science.

The situation is similar as regards motivations for seeking consultative status. It is evident, for instance, that Germany's protracted, intensive, and expensive involvement in Antarctic research more than earned that country its consultative status. Moreover, when working towards achieving that status, Germany did so essentially for reasons connected with science. Alternatively, it is doubtful whether the same could be said of North Korea, which is currently attempting to gain consultative status at the price of some Antarctic winterings. North Korea's aspirations might well be prompted by South Korea's having already gained such status and, more generally, by a wish to break out of its political isolation.

To be reasonably complete, it would now appear necessary to examine the extent to which the governments of the Consultative Partiesare guided by scientific motivations in their meetings. This could be a perilous undertaking, however, for governments do not, as a rule, explain the inner workings of their decision-making processes; when they do, their explanations cannot always be taken at face value. In addition, the Consultative Parties meet behind closed doors and provide very little information about their debates and decisions. However, a simple look at the composition of governmental delegations, which include numerous scientists, suggests that scientific considerations loom large in the ongoing construction of the Antarctic system.

The action of international organisations in the Antarctic framework

International organisations may be divided into intergovernmental agencies and non-governmental organisations (NGOs). Both have played and continue to play a significant part in the international affairs of Antarctica. Some of them operate within the Antarctic system; others attempt to influence or combat that system from the outside.

Among the intergovernmental agencies that have traditionally contributed to the construction of the Antarctic regime are a number of regional agencies, such as fisheries commissions. On the universal level, there are technical organisations of the United Nations family such as the World Meteorological Organisation, the Food and Agricultural Organisation, the International Maritime Organisation, the International Oceanographic Commission, and the United Nations Environment Programme. However, the head of that family, the United Nations itself, has been excluded from consultative and other meetings (UN 1990; 
1991). The organisations and organs in question have participated actively in the shaping of Antarctic legislation, for instance in the preparation of the Protocol on Environmental Protection to the Antarctic Treaty, which was adopted by the Eleventh Special Consultative Meeting on 4 October 1991. In view of the predominantly technical character of those organisations and organs, their positions are likely to be founded at least partly on scientific considerations.

While the participation of intergovernmental organisations in the international law-making process generally has come to be increasingly accepted since the end of World War II, the reverse is true for NGOs. Though many of them enjoy consultative status in the framework of the Economic and Social Council of the United Nations, they have no formal standing in most forums where intergovernmental matters are discussed. Accordingly, they have to rely on states, intergovernmental agencies, and the media to put across their views.

This description does not, however, apply to Antarctic affairs. The regime of the seventh continent, as it began to emerge in 1959, was at least partly the work of ICSU, a non-governmental international body of scientists, the actions of which proceeded from scientific considerations. In addition, SCAR is mentioned in a number of resolutions adopted through the years at Consultative Meetings and is granted advisory functions in the 1972 London Convention on the Conservation of Antarctic Seals, the 1980 Canberra Convention on the Protection of Marine Living Resources, and the Protocol on Environmental Protection to the Antarctic Treaty (International Legal Materials 1972, 11: 251; 1980, 19: 860). It is evident that SCAR's advice is based on scientific elements. It is also evident that, by equipping parts of the Antarctic system with consultation mechanisms involving a non-governmental scientific body, the Antarctic community has taken a pioneering attitude both in institutionalising recourse to scientific advice and in entrusting the advisory function to an NGO.

In recent years, the Antarctic community has been confronted with a second, quite different, generation of NGOs. A large number of private bodies active on the trans-national level have formed the Antarctic and Southern Ocean Coalition (ASOC). Throughout the Eleventh Special Consultative Meeting on the Protection of the Environment, ASOC has enjoyed observer status equal to that of SCAR; in addition, several of its member organisations are represented in governmental delegations. Endowed with considerable financial means and great mastery in handling the media, this federation of NGOs, which includes Greenpeace, has been crusading in favour of a 'World Nature Park Antarctica', a concept that may eventually collide with the requirements of scientific research. The crusade has been spectacularly successful: Greenpeace and its associates have been able to engineer the downfall of the 1988 Wellington Convention on Mineral Resources (International Legal Materials 1988, 27:868) and to pave the way for the Protocol on Environmental Protection to the Antarctic Treaty. In a sense, this new breed of NGOs on the Antarctic scene is more powerful than the traditional ones wedded to scientific ideals. The new scale of values is dominated by a predominantly political preoccupation: the preservation of the environment. There is no reason to criticise this choice; scientific aims are not in and of themselves good, just as political objectives are not invariably bad, or vice versa. The conclusion to be drawn from this is that the NGOs of a scientific character, which played such a major role in the shaping of the Antarctic regime, are at the moment being overshadowed by NGOs with a more political outlook.

The entities mentioned so far were those operating inside the Antarctic system. The United Nations has always been kept at bay by the 26 Consultative Parties. This, as well as the discrimination between Treaty Parties with and without consultative status, has been deeply resented by the majority of the members of the organisation, which are developing countries. They point out that the fate of Antarctica is of universal concem. Yet would it not be both incongruous and impractical to entrust the management of that continent to states a majority of which have never been effectively present in it, have never shown any real interest in it, and have never conducted research related to it?

It would seem that in reality most members of the United Nations are guided not exclusively by preoccupations relating to the freedom of scientific research or the protection of the Antarctic environment, nor by concerns over the general well-being of mankind. Their ultimate aim is to achieve the downfall of the "Antarctic aristocracy' as a symbol of inequality. This attitude may call for criticism. So may the inconsistency of the Consultative Parties, which ban the United Nations from their meetings while inviting its technical agencies to participate in them.

\section{Conclusions}

Regimes and institutions, on both national and international levels, are the results of political action. Such action should be attuned to social needs.

In the case of Antarctica, one such need was and remains the creation of optimal, or at least acceptable, conditions for the conduct of scientific research. That Antarctic research is in the interest not only of scientists but of the world community has been well demonstrated. Accordingly, politics ought to be the servant of science.

But politics should serve equally other social values deserving protection. In certain situations, for instance, the requirements of scientific research could clash with the status of Antarctica as a peace zone, or with environmental concerns. Different social values will have to be weighed against each other and to be either reconciled or placed in an order of preference.

Legislators, administrators, and funding agenciesshould be the servants, not the slaves, of science, although some scientists seem to think that they are entitled to whatever they want and need, the usual justifications given being the 'relevance' and 'quality' of the work proposed. But society (that is, the taxpayer) may not, and perhapseven should not, accept those justifications blindly. 
Scientists must take the time to communicate, to explain and justify their needs. On the domestic level, the national academies of science are very helpful in channelling the interaction between science and politics. On the international level, as regards the Antarctic, this function is assumed by SCAR, which has one foot in the realm of science and the other in the field of politics. In Antarctic matters, SCAR thus provides the indispensible link of communication between science and politics.

\section{References}

Auburn, F. M. 1982. Antarctic law and politics. London, Hurst.

Treves, T. 1987. The United Nations General Assembly, Antarctica and the Law of the Sea Convention. In: Francioni, F., and Scovazzi, T. (editors). International law for Antarctica. Milan, Giuffrè.

UN. 1990. United Nations GeneralAssembly Records 44th Session. Resolution, 26 January 1990, A44/124.

UN. 1991. United Nations GeneralAssembly Records 45th Session. Resolution, 14 January 1991, A45/78.

\section{Report from the First Annual Confer- ence of the National Institute for Global Environmental Change}

\section{Torben Christensen}

Scott Polar Research Institute, Lensfield Rd., Cambridge CB2 1ER

\section{Received February 1992}

The National Institute for Global Environmental Change (NIGEC) is a major new US research programme dedicated to interdisciplinary study of global climate and environmental change. NIGEC was established in 1990 on the basis of a cooperative agreement between the University of Califormia Board of Regents and the US Department of Energy. It has five regional centers that received \$6 million for their start-up year.

The institute held its first annual conference at Huntington Beach, California, 5-10 January 1992. The focus of the conference was atmospheric methane covering sources, sinks, OH chemistry, isotopic composition, ice-core records, trends in atmospheric concentration, and modeling efforts of land cycling and atmospheric decomposition. The conference also dealt with aspects of ozone, oxygen, carbon dioxide, and nitrous oxide.

The polar regions play a major role in problems addressed by the conference. Wetlands (including tundra) of high northem latitudes represent a substantial part of the global natural wetlands which are believed to be among the largest sources of atmospheric methane. Permafrost and near-shore areas in the Arctic contain enormous amounts of gas hydrates (consisting largely of methane), which, if released, could make a significant contribution to climate warming. Ice-core records from Greenland and Antarctica contain invaluable information about changes in atmospheric concentrations of carbon dioxide and methane over the past 160,000 years. There also seems to be a decrease in the growth rate of atmospheric methane over high northern latitudes, a pattern that is not fully understood. Finally, a relatively large biogenic source of atmospheric carbon dioxide has been observed over high northern latitutes possibly associated with a changing carbon balance of the tundra or deforestation of taiga in Canada and Siberia.

The following is a short overview of chosen presentations. A total of 37 talks and 15 posters were presented at the conference.

In an introductory plenary lecture Dieter Ehhalt (KFA, Germany) gave an overview of the atmospheric methane budget and focused on the importance of $\mathrm{CH}_{4}$ in atmospheric chemistry. He showed that the effect on global climate of $\mathrm{CH}_{4}$ is not limited to its own radiation. By being the main determinant for atmospheric concentrations of $\mathrm{CO}, \mathrm{OH}$, and various other compounds $\mathrm{CH}_{4}$ has far reaching consequences for reactions that determine atmospheric concentrations of $\mathrm{O}_{3}, \mathrm{~N}_{2} \mathrm{O}$, and CFCs.

Bill Reeburgh (University of Alaska, Fairbanks) gave a new view on the atmospheric methane budget, detailing the actual amounts of gross production and consumption of methane that lies behind the net budget as it normally is presented. He suggested a gross global methane production of $1274 \mathrm{Tg} \mathrm{CH}_{4} \mathrm{yr}^{-1}$ of which $774 \mathrm{Tg} \mathrm{CH}_{4} \mathrm{yr}^{-1}$ are consumed by microbial methane oxidisers before entering the atmosphere, giving the well known net source figure of about $500 \mathrm{Tg} \mathrm{CH}_{4} \mathrm{yr}^{-1}$. These figures emphasize the importance of the oxidisers in the study of how net emissions are controlled and how they might change under a global warming scenario. The difference between gross and net production is largest in the terms of rice paddies, bogs (boreal), tundra, and ocean/freshwater emissions, pointing to these as important areas for the study of microbial methane oxidation.

Bob Harris (University of New Hampshire) presented a regional study of methane emissions from the Florida Everglades. His group has quantified emissions from this region by use of satellite images: 13 different vegetational units have been identified on the images, and subsequent ground based flux studies in these units have produced the basis for a methane emission map. He then showed how land use developments in the region have changed the emissions through history. Natural emissions were estimated to have decreased by about $75 \%$ since the year 1900 , but agriculture and urban activities have increased similarly and the anthropogenic sources are now estimated to have exceeded natural wetland emissions from the area.

Mark Castro (Woods Hole) presented a study of the processes controlling methane oxidation rates in temperate forest soils. He indicated that nitrogen additions and increasing moisture lowered the uptake rates. There was a significant correlation between flux rates and average soil temperature (in the spring for the month preceding the flux measurements), and this correlation was used to establish 